\title{
US - Shrimp \\ United States - Import Prohibition of Certain Shrimp and Shrimp Products: Recourse to Article 21.5 of the DSU by Malaysia*
}

ROBERT HOWSE AND DAMIEN J. NEVEN

\section{Introduction}

This study discusses the ruling of the Appellate Body (AB) in the recourse to Article 21.5 of the DSU by Malaysia in the context of the US import prohibition of certain shrimp and shrimp products from a legal and economic perspective. The first part of the chapter (section 2) discusses the background of the case, and, in particular, presents the main issues at stake in the Panel and $\mathrm{AB}$ decisions in the original case as well as their main findings. Section 3 discusses the key elements of the compliance panel and its subsequent appeal and identifies a few issues that are discussed in further detail. In section 4 , in the context of a simple model, we first consider the consequences of making imports contingent on the adoption of environmental measures in exporting countries. We find that the attractiveness of such measures depends heavily on the characteristics of abatement technology and the range of policies available in the exporting countries. Finally, section 5 briefly discusses the trade-off between flexibility in the imposition of environmental standards and the enforcement of dispute settlements' rulings.

\section{Factual background ${ }^{1}$ and summary of legal issues and findings}

\subsection{Protection of sea turtles by the United States}

Several species of sea turtles are endangered. In the 1980s, in an effort to protect these species, the United States enacted measures to reduce the

* This study was prepared in the context of the American Law Institute project on the Principles of World Trade Law.

1 The material in this section draws heavily on Howse (2002). 
number of sea turtles killed by US trawlers. The most important measure was a requirement that every US trawler fishing waters inhabited by sea turtles be equipped with a Turtle Excluder Device. In 1989, the United States attempted to impose the Turtle Excluder Device requirement on shrimp trawlers elsewhere in the world.

Section 609 of the law on the "Protection of sea turtles in shrimp trawl fishing operations" contained several elements. First, it required the US State Department to (1) commence negotiations as soon as possible for concluding bilateral and multilateral agreements to protect sea turtles and to (2) promote other international environmental agreements to better protect sea turtles. Second, it required the State Department to report to Congress within a year on the practices of other countries affecting the mortality of sea turtles. Third, it prohibited the importation of any shrimp harvested using commercial fishing technologies that might harm sea turtles, unless the exporting country is certified by the US administration as having a regulatory program to prevent incidental turtle deaths comparable to that of the United States, or is certified as having a fishing environment that does not pose risks to sea turtles from shrimping. Until 1995, the State Department had only applied the requirements of this section to the Caribbean area and did so on the basis of a program to require trawlers to be equipped with Turtle Excluder Devices. In 1995, environmental NGOs challenged the decision of the State Department to limit the application of section 609 to the Caribbean area before the US Court of International Trade.

The Court of International Trade held that there was no statutory basis for limiting the law to the Caribbean region. In a subsequent court action, the State Department asked the court to extend the deadline for application of the embargo to other countries beyond 1996, arguing that this deadline would provide inadequate opportunity for other countries to adopt the measures necessary to be certified. The Court of International Trade denied this request. This led the State Department to promulgate a series of guidelines for enforcement of the statute, which permitted entry into the US of shrimp that were declared to be caught with Turtle Excluder Device technology, even if the country concerned could not be certified as having a regulatory program comparable to that of the US. These guidelines were in turn challenged by NGOs in further proceedings at the Court.

The Court held that Congress had intended that the main operative provision of section 609 , which banned shrimps caught with commercial 
fishing technology harmful to endangered species of sea turtles, in fact applied to all shrimps not originating from certified countries, regardless of whether the imported shrimps themselves were caught by boats equipped with Turtle Excluder Device technology.

On the day of the Court of International Trade judgment, India, Malaysia, Pakistan, and Thailand took the matter to dispute settlement at the WTO. The United States chose not to dispute explicitly the complainants' argument that the shrimp embargo was a violation of Article XI GATT, which bans non-tariff prohibitions or restrictions on imports. The United States based its defense of the measure strictly on the claim that they were justified under Article XX.b or g GATT. Article XX GATT provides exceptions (to Article XI GATT) for measures that are "necessary" to protect human and animal health (XX.b) and measures enacted "in relation to" the conservation of natural resources (XX.g).

\subsection{The original Panel and Appellate Body rulings}

While much of the legal arguments of the parties, as well as their factual claims, addressed whether the embargo could be justified under Article XX.b or g GATT, the Panel chose to pin its legal analysis exclusively on a consideration of whether the embargo satisfied the chapeau, i.e. the general provisions of Article XX GATT. It stipulated that measures should not be applied "in a manner which would constitute a means of arbitrary or unjustifiable discrimination between countries where the same conditions prevail, or a disguised restriction of international trade."

The Panel ruled that unilateral measures conditioning market access to the adoption of certain policies by exporting countries were not consistent with the chapeau. According to the Panel, if such unilateral measures were accepted, the WTO agreement could "no longer serve as a multilateral framework for trade among Members as security and predictability of trade relations under those Agreements would be threatened. This follows because if one WTO Member were allowed such measures, then other Members would also have the right to adopt similar measures on the same subject but with differing, or even conflicting, policy requirements. Indeed, as each of these requirements would necessitate the adoption of a policy applicable not only to export production, but also to domestic production, it would be impossible for a country to adopt one of these policies without the risk of breaching other Members' conflicting policy 
requirements for the same product and being refused access to these other markets."

The United States appealed this ruling. The $A B$ reversed the findings of the Panel on two important issues. Importantly, the $A B$ also went forward to apply the law, as correctly understood, to the facts of the case.

\subsubsection{Negative findings}

First, the $\mathrm{AB}$ found that the Panel had made an error of law in assuming that unilateral measures that condition market access on the policies of exporting countries were, as a matter of principle, not justifiable under Article XX GATT. In particular, paragraph 121 reads: $^{2}$

In the present case, the Panel found that the United States measures at stake fell within the class of excluded measures because section 609 conditions access to the domestic shrimp market of the United States on the adoption by exporting countries of certain conservation policies prescribed by the United States. It appears to us, however, that conditioning market access to a Member's domestic market on whether exporting Members comply with, or adopt, a policy or policies unilaterally prescribed by the importing Member may, to some degree, be a common aspect of measures falling with the scope of one or another of the exceptions (a) to (j) of Article XX. It is not necessary to assume that requiring from exporting countries compliance with, or adoption of, certain policies (although covered in principle by one or another of the exceptions) prescribed by the importing country, renders a measure a priori incapable of justification under Article XX. Such an interpretation renders most, if not all, of the specific exceptions of Article XX inutile, a result abhorrent to the principles of interpretation we are bound to apply.

This finding represents a radical shift in approach from the Tuna/ Dolphin cases. To the extent that the $\mathrm{AB}$ did not have to rely on this finding to reverse the Panel decision, some interpreted this paragraph as dicta, of uncertain legal significance in future cases.

Second, the AB found that the Panel should have applied a sequential approach in dealing with Article XX GATT, such that it should have first considered whether the measure could be justified under one of the heads of Article XX GATT and then only if there was such provisional justification, to consider whether the party maintaining the measure was

2 WTO Appellate Body Report on US - Import prohibition of Certain Shrimp and Shrimp Products, WT/DS58/AB/R, October 12, 1998. 
in compliance with the chapeau. The AB stressed that the chapeau is concerned only with the application of measures, not whether the measures themselves are justified under Article XX GATT. According to the AB (paragraph 15),

In the present case, the Panel did not expressly examine the ordinary meaning of the words of Article XX. The panel disregarded the fact that the introductory clauses of Article XX speak of the "manner" in which measures sought to be justified are applied. What the panel did, in purporting to examine the consistency of the measure with the chapeau of Article XX, was to focus repeatedly on the design of the measure itself. The general design of a measure, as distinguished, from its application, is, however, to be examined in the course of determining whether that measure falls within one or another of the paragraph of Article XX following the chapeau.

\subsubsection{The positive findings}

The $\mathrm{AB}$ went on to complete the sequential analysis. The first stage involved the question whether the measure was covered by any of the specific heads of Article XX GATT. The AB considered that turtles could be seen as an exhaustible resource within the meaning of Article XX.g GATT and further analyzed whether the measure was "in relation" with its conservation. In doing so, the AB applied a "rational connection" or reasonableness standard and easily found that the measure met this standard.

There is some evidence however that, beyond rational connection, the $\mathrm{AB}$ was using some conception of proportionality. Thus, the $\mathrm{AB}$ not only held that there was a direct connection between the main features of the US scheme and the conservation of sea turtles, but also found that "section 609 , cum implementing guidelines, is not disproportionately wide in its scope and reach in relation to the policy objective of protection and conservation of sea turtle species." What the $\mathrm{AB}$ appears to mean here by proportionality in scope and reach, is whether all the trade-restricting features of the scheme have some reasonable connection to turtle conservation. It does not appear to be balancing in any way the environmental benefits against the costs to trade entailed in the measure. Thus, the $A B$ does not engage in the analysis of the trade-off between the benefits of the measure in terms of environmental protection and its costs in terms of trade restrictions.

With respect to the second stage (whether the implementation of the measure met the conditions of the chapeau), the $\mathrm{AB}$ found that the 
failure of the State Department to negotiate seriously with the complainants constituted "unjustifiable discrimination." This was a failure in implementation since section 609 itself contained a requirement to negotiate with all relevant countries. In addition, the $A B$ found that the implementation involved unjustifiable discrimination because (i) the Panel were applying a rigid, extraterritorial extension of US law to other countries and because (ii) the Panel wholly disregarded the conditions prevailing in other countries.

To be certified and hence gain access to the US markets, all countries were required to have a Turtle Excluder Device program essentially identical to that of the US, regardless of the conditions prevailing in those countries. This was certainly discriminatory in comparison to the agreement embodied in the Inter-American Convention for the protection and conservation of sea turtles, which allowed the specific circumstances of the exporting countries to be taken into account in determining the means they adopted to satisfy the US conservation objectives. It was unjustified because, as the $\mathrm{AB}$ suggests, other measures more acceptable to the exporting country might have achieved the legitimate conservation objective of the US. Section 609 itself allowed for the possibility of certification in the case of a turtle conservation program comparable to that of the US.

The $\mathrm{AB}$ also noted that since the US guidelines did not allow for shipment by shipment certification, shrimp caught with a Turtle Excluder Device could be barred because they happened to have been caught in waters that were not certified. The $A B$ saw this as evidence that section 609 was applied more as an extraterritorial extension of US law than a global conservation measure. The $\mathrm{AB}$ also found the existence of arbitrary discrimination in the manner in which section 609 was applied, citing lack of transparency in the certification process.

\section{The Compliance Panel and Appellate Body ruling}

Following the $\mathrm{AB}$ ruling, the US modified the guidelines implementing section 609. The revised guidelines dropped the requirement that exporting countries should use Turtle Excluder Devices and allowed for certification if the exporting countries could show that they were enforcing a regulatory program without devices that was comparable in effectiveness to those using devices. The revised guidelines also allowed for certification if fishing conditions in the exporting country did not pose a threat of incidental capture of sea turtles. Finally, the revised guidelines allowed 
for shipment by shipment certification, and greater transparency and due process.

\subsection{The Panel decision}

Of the complainants in the original action, Malaysia alone filed a complaint under 21.5, alleging that the changes that the United States made in the manner of implementation of section 609 did not satisfy the conditions of the chapeau as articulated by the AB. The Panel found that, in all relevant respects, the United States had met its obligations under the chapeau and that its measure was now in conformity with the requirements of the GATT treaty. The core of the Panel's decision related to its interpretation of the kind of "flexibility" that the $\mathrm{AB}$ was requiring in order for the United States to meet the requirements of the chapeau; this core aspect was the basis of Malaysia's further appeal of the 21.5 Panel ruling to the $A B$. Thus, we will discuss it below in our analysis of the $A B$ 21.5 ruling. However, there are several curious or troubling features of the 21.5 Panel ruling that were not the subject of appeal or cross-appeal, and did not attract direct comment by the AB. These we briefly elaborate on in what follows.

\subsubsection{Jurisdiction of the 21.5 Panel; the threshold question}

It has been repeatedly held by the $\mathrm{AB}$ that a panel may only consider claims based on articles of the Covered Agreements that are listed in the request for a panel. The minimum level of specificity at which these must be listed is the article itself; however, a greater degree of specificity may be required where necessary for the defending party to be fully apprised of the case against it.

In Malaysia's request for a 21.5 Panel, Malaysia did not cite any articles of the covered agreements with which it was claiming the new US measures were inconsistent (Recourse by Malaysia to Article 21.5 DSU, WT/DS58/17). In Article 5.10 of its report, the 21.5 Panel stated that it took no position on whether pursuant to the interpretation of DSU 6.2 in $\mathrm{AB}$ reports, Malaysia had failed to state the provisions of the covered agreements on which it was relying in its claim with adequate specificity. This was an error of law.

The request for a panel is a crucial element in the establishment of the panel's jurisdiction (European Communities-Bananas III, Report of the Appellate Body, adopted September 25, 1997, WT/DS27/AB/R, paragraph. 141), and the Panel erred in assuming that it possessed jurisdiction 
without determining the adequacy of the request for the panel in light of DSU 6.2. The Panel's justification for so proceeding was that the United States did not claim that the request for the Panel was inadequately specific. However, the minimum requirement that the articles of the DSU upon which a member is relying be stated in its request for a panel is not one that can be waived by the defending party. This is a matter of due process in dispute settlement generally and goes to the panel's jurisdiction.

A request for a panel alerts all WTO members to the substance of the complaining Member's claim and may affect their decision as to whether to seek third-party rights in a given proceeding. As the $\mathrm{AB}$ re-emphasized in the Korea - Dairy case, a panel has a duty to consider carefully the request for the panel, and to make a decision on its adequacy as against the standard set out in Article 6.2 of the DSU (Korea-Dairy, paragraph 122). To be sure, by listing an article of a covered agreement in its request for a panel, and claiming this article to have been violated, a complaining Party may be able to make a claim concerning other provisions of the covered agreements, where these other, unlisted, provisions are incorporated by reference, as it were, through the listed articles. However, Malaysia's request for a Panel does not contain a list of any articles of any covered agreement with which Malaysia claims the new US measures are inconsistent.

Unless otherwise so specified, or unless such an interpretation would be manifestly absurd or unreasonable, provisions of the DSU that apply to a panel apply, mutatis mutandis, with respect to a 21.5 panel: the term "panel" is an expression with a special meaning within the DSU, and, applying Article 31.4 of the Vienna Convention, this special meaning as defined in numerous provisions of the DSU should be given to its usage within 21.5 except where the treaty text itself modifies that meaning in the case of 21.5 panels (for example, time limitations). Article 21.5 panels have consistently assumed that provisions of the DSU and rules of panel procedure apply to 21.5 proceedings - a recent example is Brazil - Export Financing Programme for Aircraft, Second Recourse to Article 21.5 of the DSU, where the Panel examined Brazil's claim concerning confidentiality of documents against the provisions of the DSU applicable generally to panels (paragraphs 3.1-3.15).

\subsubsection{Country-by-country vs. shipment-by-shipment inspection}

In completing the analysis in the original $A B$ decision in this case, the $A B$ identified several differences in the manner in which the US scheme was applied to different shrimp-exporting countries, which amounted 
"cumulatively" to unjustifiable discrimination within the meaning of the chapeau. One of the features in question that contributed to the existence of "unjustifiable discrimination "was" country-by-country application of the legislation." Thus, even where a particular shipment of shrimp was fished in a manner consistent with the conservation objectives of the United States, it would not be permitted to enter the United States unless the country of origin was certified to have a regulatory program for turtle conservation essentially identical to that of the United States.

In its report the 21.5 Panel correctly found that the United States' change to shipment-by-shipment certification was one respect in which its new measure could be considered not to contribute to the existence of "unjustifiable discrimination." However, the 21.5 Panel went further and held that "[t]his condition is addressed separately from the broader category concerning lack of flexibility and insufficient consideration of the conditions prevailing in the exporting countries because, in our opinion, it required a specific solution, while the other findings left more discretion to the United States" (paragraph 5.106).

This treatment of country-by-country vs. shipment-by-shipment certification is unwarranted by anything in the $\mathrm{AB}$ report. The $\mathrm{AB}$ considered the country-by-country aspect of the scheme, in one of a series of continuous paragraphs in the section of its report under the heading "Unjustifiable Discrimination," in which it dealt with all the other aspects bearing on "unjustified discrimination" as well; the section as a whole ends in a single finding of unjustifiable discrimination in the ultimate paragraph, based upon the cumulation of the various aspects identified throughout the section.

The paragraph in which country-by-country certification is discussed (165) begins with the word "Furthermore," and is followed by a paragraph that begins with the expression "Another aspect..." This makes it clear that country-by-country certification is being dealt with by the $\mathrm{AB}$ as one of a series of aspects of the application of the scheme that, cumulatively, result in "unjustifiable discrimination" within the meaning of the chapeau. Contrary to the implication of the Panel, the AB did not suggest that country-by-country certification required a "specific solution." Its recommendation, in paragraph 188 of its report, is the standard recommendation that the US bring itself into conformity with the provisions of the covered Agreement in question, and there is no suggestion of a "specific solution," nor any distinction drawn between, on the one hand, elements of discretion in the means taken by the US to implement the 
$\mathrm{AB}$ report and, on the other, actions that the $\mathrm{AB}$ believes must be taken by the US in order to bring itself into conformity.

\subsubsection{Article XX GATT as an emergency clause}

In paragraph 5.88 of its report, the 21.5 Panel makes the following statement:

Finally the Panel would like to clarify that, in a context such as this one where a multilateral agreement is clearly to be preferred and where measures such as that taken by the United States in this case may only be accepted under Article XX if they were allowed under an international agreement or if they were taken further to the completion of serious good faith efforts to reach a multilateral agreement, the possibility to impose a unilateral measure to protect sea turtles under 609 is more to be seen, for purposes of Article XX, as the possibility to adopt a provisional measure allowed for emergency reasons than as a definitive "right" to take a permanent measure. The extent to which serious good faith efforts continue to be made may be assessed at any time. For instance, steps which constituted good faith efforts at the beginning of a negotiation may fail to meet that test at a later stage.

Here, perhaps, the Panel merely wished to point out that, inasmuch as it imposes conditions on the exercise of rights under Article XX GATT that relate to the application of measures, any ruling of a 21.5 panel concerning consistency with the chapeau is of a contingent or provisional character. A ruling that US officials are currently applying section 609 in a manner consistent with the chapeau could hardly immunize future acts of US officials from review under 21.5. In this sense, all the rights in Article XX GATT are indeed provisional, as the continuing justifiability of the measure under this article depends on the ongoing application of the measure being consistent with the chapeau.

However, in making this point, the 21.5 Panel went too far, in suggesting that, as a matter of law, the US in order to maintain its measure as justified under Article XX GATT, must never cease to make further serious good faith efforts to negotiate a multilateral agreement. Whether any particular shortfall or curtailment of negotiating efforts at a future point in time might constitute "unjustifiable discrimination" within the meaning of the chapeau, would have to be assessed by a 21.5 panel at that point in time, in light of all the facts. For example, if the United States were to curtail or suspend negotiating efforts after the failure of prolonged, costly, and intense negotiations to produce an agreement, such a decision would far from necessarily amount to unjustifiable discrimination between countries 
where similar conditions prevail. Moreover, certain wording in this statement by the panel ("may only be accepted under Article XX ..." [emphasis added]) suggests that the 21.5 Panel may have misunderstood the $A B$ as reading a condition into the chapeau of Article XX GATT that is not based on the treaty text, rather than simply interpreting and applying the words "discrimination" and "unjustifiable" in the particular facts of this dispute.

The chapeau of Article XX GATT does not contain a positive duty to negotiate, regardless of the unilateral character of the measures in question; however, the elements of unilateralism discussed by the Appellate Body, might well lead to discriminatory behavior in respect of negotiations crossing the threshold of unjustifiable discrimination. But this is a matter of applying, on a case-by-case basis, the text of the chapeau to the full factual record and legal context. Here, it should be noted that the duty of cooperation pointed out by the $\mathrm{AB}$ in its discussion of the law of sustainable development in its original decision in this dispute is a duty on all States affecting and affected by the global common problem at issue (paragraph 168, citing Article 5 of the Convention on Biodiversity): any assessment of the future negotiating behavior of the United States would also require a concomitant consideration of the related behavior of other States implicated in the same environmental situation.

\subsection{The AB ruling}

Malaysia appealed on two grounds. First, Malaysia claimed that the Panel did not properly fulfill its mandate. According to Malaysia, the Panel considered the consistency of the compliance measure implemented by the US with the recommendations of the $\mathrm{AB}$ in the original decision but should have considered whether the compliance measures were consistent with GATT's agreement.

Second, Malaysia disagreed with the Panel's conclusion that the reformed guidelines are consistent with the chapeau of Article XX GATT, namely that they no longer constitute an arbitrary or unjustifiable discrimination between countries where the same conditions prevail.

\subsubsection{Scope of the review}

With respect to the first claim, the $\mathrm{AB}$ confirmed that the mandate of the Panel is to consider the compliance measure in its "totality" and indeed to consider the consistency of the compliance measures with respect to GATT's agreement but that the task of the Panel is limited by the claims 
made by the parties. The $\mathrm{AB}$ thus concluded that it would be inappropriate to consider issues that have not been raised.

One issue however arose with respect to the interpretation of what is meant by the "totality" of a compliance measure and in particular whether the Panel should have considered again those aspects of the compliance measures that were found to be GATT-consistent by the original Panel. The $A B$ did not rule this out (paragraph 91) suggesting that, since section 609 of the law was part of the new measure, it was not immune from scrutiny. However, the $\mathrm{AB}$ also reiterated the distinction between the measure adopted by the US (namely section 609) and the implementation of the measure through guidelines.

The AB emphasized that only the implementation of Section 609 had been considered unlawful by the original decision (i.e. did not benefit from the exception of Article XX GATT) and not section 609 itself. The AB found that the application of the original measure that denied the original measure the benefit of Article XX GATT were unrelated to the original measure itself. Accordingly, the $\mathrm{AB}$ concluded that the panel did not have to consider again the consistency of section 609 with GATT's agreement. The $\mathrm{AB}$ agreed with the Panel's finding that the "revised guidelines do not modify the interpretation given to section 609" and that there is "no evidence" that the revised guidelines have modified in any way the meaning of section 609 vis-à-vis the requirements of paragraph (g), as interpreted by the $\mathrm{AB}$.

\subsubsection{Requirements of the chapeau}

Malaysia claims that the revised guidelines still violate the chapeau of Article XX GATT on, essentially, two grounds. First, Malaysia claims that the US should have not only negotiated but also concluded an international agreement on the protection of sea turtles before imposing an import prohibition. Malaysia points out that if the requirement is only to negotiate, as long as the negotiation is not concluded, defendants could end up imposing unilateral measures which would constitute "unjustifiable" discrimination.

The $\mathrm{AB}$ ruled that a requirement to conclude an international agreement would be unreasonable - essentially because it would grant a veto right to every single party to the negotiation on whether a country fulfills its WTO obligations (paragraph. 123): ${ }^{3}$

${ }^{3}$ Report of the AB, US - Shrimp; Recourse to Article 21.5 of the DSU by Malaysia, WT/DS58/AB/RW (October 22, 2001). 
Requiring that a multilateral agreement be concluded by the United States in order to avoid arbitrary or unjustifiable discrimination in applying the measure would mean that any country party to the negotiations with the United States, whether a WTO Member or not, would in effect have a veto right over whether the United States could fulfill its WTO obligations. Such a requirement would not be reasonable.

Second, Malaysia challenged the panel's interpretation of the chapeau's flexibility requirement. As indicated above, the original $\mathrm{AB}$ decision found that the US could not require other countries to adopt its own regime of protection of sea turtles. According to the AB, this would constitute arbitrary discrimination.

The Compliance Panel found (relying on the original AB decision) that a requirement that foreign programs should be comparable in effectiveness would be compatible with the chapeau of Article XX GATT and hence would not constitute arbitrary discrimination. Malaysia disagreed and noted that the US will retain the power to decide which programs can be considered as comparable in effectiveness. According to Malaysia, awarding a veto right to the US with respect to alternative programs implies that the US measure results in arbitrary or unjustifiable discrimination.

Malaysia further argued that the AB's ruling in the original case that "conditioning access to a Member's domestic market on whether exporting Members comply with, or adopt, a policy or policies unilaterally prescribed by the importing Member may, to some degree, be a common aspect of measures falling within the scope of one or another of the exceptions (a) to ( $\mathrm{j}$ ) of Article XX," was mere dicta.

The AB emphasized that the principle expressed by this statement was not mere dicta, but rather a principle that was "central" to its ruling. The $\mathrm{AB}$ further amplified the distinction between the imposition of identical measures and the imposition of measures that are comparable in effectiveness. The $A B$ emphasized that the latter gives sufficient latitude to the exporting countries to adjust to the specific conditions that they face (paragraph 144).

In our view, there is an important difference between conditioning market access on the adoption of essentially the same program, and conditioning market access on the adoption of a program comparable in effectiveness. Authorizing an importing Member to condition market access on exporting Members putting in place regulatory programs comparable in effectiveness to that of the importing Member gives sufficient latitude to the exporting Member with respect to the program it may adopt to achieve the level of 
effectiveness required. It allows the exporting Member to adopt a regulatory program that is suitable to the specific conditions prevailing in its territory. As we see it, the Panel correctly reasoned and concluded that conditioning market access on the adoption of a program comparable in effectiveness, allows for sufficient flexibility in the application of the measure, so as to avoid "arbitrary or unjustifiable discrimination." We, therefore, agree with the conclusion of the Panel on "comparable effectiveness."

\subsection{Issues raised by $A B$ ruling}

The $\mathrm{AB} 21.5$ ruling raises at least two important issues. First, the $\mathrm{AB}$ compliance ruling, has confirmed, definitively, that imports can be made contingent on environmental standards that are determined unilaterally by the importing nation. The importance of this final determination should not be underestimated. It effectively reverses the initial Panel ruling but also stands in stark contrast with the general approach adopted by panels in other cases where environmental measures were at stake. For instance, in both Tuna/Dolphin cases, the Panel had ruled that an embargo on tuna which was not fished in a dolphin friendly manner, could not be justified under Article XX. ${ }^{4}$

It is thus not surprising that this new doctrine has been subject to controversy. For instance, Bhagwati (2001) commenting on the original $\mathrm{AB}$ decision (which was confirmed by the $\mathrm{AB}$ compliance ruling on this point) suggested that the $A B$ had indulged in illegitimate judicial activism. He offered the judgment that the $\mathrm{AB}$ had been unduly concerned about "the political pressures brought by the rich-country environmental NGOs and essentially made law that affected the developing countries adversely." He saw this as an instance where the $\mathrm{AB}$ should have deferred more to the political process. ${ }^{5}$

Section 4 of the chapter will consider the issue further and explore in the context of a simple model the consequences of allowing market access to be made contingent on the adoption of environmental standards and consider whether such concerns for "green protectionism" are well founded.

${ }^{4}$ These panel reports were however never adopted.

${ }^{5}$ Howse (2002) discusses Bhagwati's criticisms and shows that it is unwarranted from the perspective of the jurisprudence. 
The second issue raised by the $\mathrm{AB}$ ruling concerns the design of compliance measures. The trade-off between the flexibility of the compliance measures and the incentives to comply are briefly discussed in section 5 .

\section{Imports contingent on environmental measures}

The US-Shrimp case can be described as a situation where the production of one commodity (shrimps) imposes a negative externality on the citizens of one country (say, the US). The external effect arises because US citizens attach some value to the preservation of sea turtles and to the extent that the production of shrimps reduces the likelihood that turtles will survive, they suffer from a negative externality when shrimps are produced. As long as production takes place in the country concerned, the external effect can be internalized, for instance by the imposition of appropriate externality (Pigouvian) taxes. However, when production takes place in another country (say, Malaysia), for which citizens of the first country (the US) cannot design and implement regulation, external effects will not be internalized by the producing country.

Depending on the instruments available, both countries concerned may however implement policies that will effectively reduce the incidence of the external effects. Making trade contingent on the adoption of particular abatement policy or at least the adoption of particular standards towards the external effect, as explicitly allowed by the US -Shrimp ruling, is one of the possible instruments. Others may include the negotiation of international agreements between the countries concerned on the internalization of the external effects. These agreements may or may not involve a link with trade flows.

In what follows, we will focus on instruments involving trade. We will explore the welfare consequence of allowing for the US -Shrimp solution, i.e. making import contingent on the adoption of standards toward the external effect in the exporting country, in the context of a simple model. We will evaluate this instrument in different regulatory environments in the exporting country, considering for instance the effect that additional instruments like Pigouvian taxes will have on the final allocation. We will compare the US - Shrimp solution with a number of alternatives like free trade, the first best allocation, and unconstrained trade policies for both importing and exporting countries. 


\subsection{A simple model}

We use a simple model, which is a variant of the framework proposed by Ludema and Wooton (1994). ${ }^{6}$ There are two countries; the importing country $(\mathrm{H})$ and the exporting country $(\mathrm{F})$. All consumption takes place in $\mathrm{H}$ while production takes place in both countries. Let $x$ be the quantity of the good that is traded. Assume that inverse demand for imports is linear:

$$
p=a-b x
$$

The good is produced under perfect competition and the foreign inverse supply curve is also linear, where $\mathrm{q}$ is the foreign price:

$$
q=f+g x
$$

The domestic import price is given by the foreign price supplemented by any specific import tariff (r) or export tax (t).

Assume that production in the exporting country generates a nonpecuniary externality on the importing country, which reduces utility at a rate $z$ per unit of output. ${ }^{7}$ Welfare in the importing country is then given by the sum of consumer surplus, domestic producer surplus, and tariff revenues less the externality:

$$
u(x, r, z)=\frac{b x^{2}}{2}+(r-z) x
$$

having normalized autarky welfare to zero.

Similarly welfare in the exporting country, which is the sum of producer surplus and tax revenues, can be written as:

$$
v(x, s, z)=\frac{g x^{2}}{2}+t x
$$

We further assume that abatement technology is available. In the absence of any abatement, the utility cost of the externality is equal to $z=\bar{z}$ per unit of output. Abatement can however reduce the externality cost at

${ }^{6}$ Ludema and Wooton (1994) consider a two-stage game in which the exporting country can commit to an externality tax in the first stage and in which both countries set their commercial policy (respectively a tariff and an export tax) in the second stage. They also consider a game where the importing country sets a standard and the exporting country sets an externality tax. The results that they obtain for this game are fully discussed below.

${ }^{7}$ In other words, the externality is defined in terms of utility units and the externality is a constant fraction of output. 
levels $z<\bar{z}$, and the abatement cost per unit of output is given by $C(z)$, with $C^{\prime}(z)<0, C^{\prime \prime}(z)>0$. That is, a firm which produces $\mathrm{x}$ units of output and reaches an externality level of $\mathrm{z}$ will have to spend $C(z) x$ on abatement.

This framework thus assumes consumption of the good and external effects in the exporting country and the generation of external effects from production in the importing country. In a complete model, consumption in the exporting country would thus impose a negative externality on the importing country and production in the importing country might also impose a negative externality on the exporting country. Our framework effectively sets the utility cost of the external effect to zero in the foreign country. Given this, the other ingredients will be unimportant as long as optimal domestic policies are implemented.

In particular, if production in the importing country generates an external effect at home, it can be addressed by an appropriate Pigouvian tax. And consumption in the exporting country can be insulated from the effect of a production tax by an appropriate subsidy. In other words, the simple framework considered here focuses on the external effect across countries and the ability to affect the terms of trade as the only sources of distortion. From this perspective, it is best positioned to isolate the interaction between trade and (non-pecuniary) external effects across countries and trace out the consequences of the US - Shrimp solution.

Note that the external effect modeled here cannot be fully characterized as an instance of "global common" or "global public good." A problem of "global commons" would involve the adequate provision of a commodity that brings indirect costs to both countries. For instance, if both the US and Malaysia attached some value to the preservation of sea turtles, the US would set its preservation policy without considering the effect on Malaysia and vice versa. By having assumed that Malaysia does not attach any value to the preservation of sea turtles, our model is admittedly one that would have to be adapted in order to answer adequately how trade can affect the solution to global commons. ${ }^{8}$ Rather, it focuses on narrower

${ }^{8}$ One can only speculate about the effect of a Shrimp/Turtle solution on a true problem of global commons. The external effect of consumption in the exporting country on itself could be internalized by appropriate taxes imposed by the government of the importing country. As in the current framework, the external effect of production in the exporting country on the importing country could be met by making imports contingent on the adoption of appropriate policies in the exporting country. The external effect that production and consumption in the importing country would impose on the exporting country could be met by making exports contingent on the adoption of appropriate policies in the importing country. 
circumstances, where the external effect only flows from one country to the other. This may be a better description of a situation where there is a spillover across jurisdiction, such that, for instance, shrimping in Malaysia affects the annual migration of sea turtles toward (say) the US which in turn destabilizes the ecological system there.

\subsection{Commercial policy without abatement}

As a background, we first describe the outcome of free trade, the first best, and the imposition of a unilateral tariff, in the absence of any abatement technology. All formal derivations will be relegated to the appendix. In the text, we will present the main insights and illustrate them through an example. Our example assumes that $\mathrm{a}=\mathrm{b}=\mathrm{g}=1, \mathrm{f}=0$ and $\bar{z}=\frac{1}{4}$. These values are chosen in such a way that the importing country is indifferent between free trade and autarky.

Let us first note that the first best (which maximizes overall welfare) requires the imposition of a Pigouvian (externality) tax at the rate $t=\bar{z}$. The imposition of a unilateral import tariff will result from the traditional motive, namely to affect the terms of trade and the effect that tariff has on the external effect through the reduction in imports. Hence, the unilateral tariff will exceed the level that that would obtain in the absence of an externality.

In this framework, an externality tax in the foreign country is equivalent to a production tax and in turn is equivalent to an export tax. Hence, if the foreign country can impose a Pigouvian tax and the domestic country can impose an import tariff, the outcome will be equivalent to unconstrained trade, where both countries freely set their commercial policy (respectively an import tariff and an export tax). Given the nature of underlying incentives (which conforms to Prisoner's dilemma), the Nash equilibrium of the game where the domestic country sets an import tariff and the foreign country sets an export (Pigouvian) tax will thus involve higher overall protection than the unilateral tariff. In this instance, the Pigouvian tax reduces the external effect but is purely driven by the terms of trade motive.

Some preliminary observations can be made. First, given the presence of an external effect, it is not a surprise that free trade does not maximize welfare and involve trade in excess of the first best. Second, the imposition of a unilateral tariff might actually yield a better outcome in terms of overall welfare than free trade. This arises because the unilateral tariff reduces the flow of the external effect. Some of the benefit that the importing 
Table 3.1 Output and welfare without abatement technology

\begin{tabular}{lllll}
\hline \hline & $\mathrm{X}$ & Welfare H & Welfare F & Total welfare \\
\hline FT & 0.500 & 0.000 & 0.125 & 0.125 \\
FB & 0.375 & & & 0.141 \\
UT & 0.250 & 0.094 & 0.031 & 0.125 \\
UT + PT & 0.188 & 0.053 & 0.053 & 0.105 \\
\hline \hline
\end{tabular}

$\mathrm{FT}=$ free trade, $\mathrm{FB}=$ first best, $\mathrm{UT}=$ unilateral import tariff

$\mathrm{UT}+\mathrm{PT}=$ unilateral import tariff and Pigouvian tax abroad.

country obtains from the imposition of the tariff does not come at the expense of the exporting country. In the context of our example, free trade actually leads to the same level of welfare as the imposition of a unilateral tariff (see table 3.1). It is easy to check however that relative to this benchmark both a more elastic supply curve and a less elastic demand curve would lead to higher welfare with a unilateral tariff than under free trade.

Third, the simultaneous imposition of a unilateral tariff and a Pigouvian tax in the exporting country, which involve more protection than the unilateral imposition of a tariff, might also lead to higher welfare than free trade. As one would expect, this arises when the external effect is particularly strong. Specifically, a sufficient condition for free trade to dominate is that the external effect is sufficiently weak that trade is equivalent to autarky for the importing country (as in our benchmark case). If free trade is worse than autarky (i.e. when the utility cost of the externality is larger than in the benchmark case), then the simultaneous imposition of a unilateral tariff and a Pigouvian tax will yield higher welfare than free trade.

Fourth, the Nash equilibrium will be highly asymmetric with a higher import tariff than a Pigouvian tax. This arises because the importing country has a higher incentive to impose a tax (the terms of trade and the external effect). The welfare of the exporting country could still increase relative to free trade, if the foreign supply is sufficiently elastic (a higher supply elasticity raises the equilibrium Pigouvian tax and shifts surplus towards the foreign country).

Finally, it is worth considering the possibility that imports could be made contingent on the adoption of a Pigouvian tax (say $e$ ) in the 
exporting country. In particular, we assume that the level of tax is determined by the importing country, but that the revenue from the tax accrues to the exporting country. Note that such an arrangement has some desirable incentive properties - to the extent that the importing country has no incentive to set the tax in order to shift the terms of trade but solely in order to correct the external effect (while taking into consideration the consequences of reduced output in its own jurisdiction). Even if the actual Shrimp/Turtle case refers to the adoption of an abatement technology, nothing in the wording of the $\mathrm{AB}$ decision would seem to rule out other environmental policies like a Pigouvian tax.

To return to the original $\mathrm{AB}$ ruling, in considering whether the US scheme itself (as opposed to its manner of application) was consistent with Article XX GATT, the AB examined whether, within the meaning of Article XX.g GATT, the scheme was "related to the conservation of exhaustible natural resources" and noted that such a rational connection existed. The $\mathrm{AB}$ observed as well, as we discuss at the beginning of this study, that the scheme was not "disproportionately wide in scope and reach" relative to the policy objective. Thus, there is room for the adjudicator to consider the extent to which the policy instrument chosen, as opposed to other possible policy instruments, represents an appropriate fit with the objective, or whether it overreaches, causing superfluous harmful effects.

In the context of our model, it appears that the importing country will choose a corner solution; it will either choose not to impose a Pigouvian tax as a condition for imports, when the external effect is weak, or to impose a prohibitive tax, when the external effect is sufficiently strong. This arises because the imposition of a Pigouvian tax abroad deteriorates the terms of trade without reducing the external effect per unit of output. The discrete nature of the solution may be due to our assumptions that demand is linear (so that surplus is quadratic) and the assumption that the external effect is a constant fraction of output.

If the external effect per unit of output increased with the output level, an intermediate solution may be found such that imports can be made contingent on a positive but non-prohibitive Pigouvian tax. In this instance, both the importing and the exporting countries would benefit relative to autarky. More importantly, the exporting country might also benefit relative to free trade (import prices increase and the government obtains the revenues from the Pigouvian tax).

To sum up, these preliminary results first illustrate that the imposition of a environmental policy abroad (through externality taxes) affects the 
terms of trade. In the simple model considered here, it is even equivalent to an export tax. ${ }^{9}$ Exporting countries will have an incentive to set these externality taxes at a level which has nothing to do with the externality at stake but which will simply improve their terms of trade.

Second, these results confirm that allowing for unconstrained commercial policies may actually do better than free trade. Third, it also appears that making imports contingent on the adoption of externality taxes in the foreign country could actually improve the welfare of exporting countries. Making trade contingent on environmental protection does not necessarily hurt developing countries even if they do not value the resources being protected.

\subsection{Contingent imports with abatement technology}

As discussed above, the US - Shrimp ruling allows for imports to be made contingent on the adoption of an abatement technology or at least the adoption of a particular standard with respect to the external effect. This is modelled in our framework as a policy where the domestic country chooses a level of external effect $z$ and in which the exporting country can meet this level of external effect through the adoption of the only abatement technology available. As before, we will consider the adoption of such a policy both when the exporting country is allowed to impose a Pigouvian tax and when is it barred from doing so.

Consider first the imposition of a standard, which can only be met by the adoption of the available abatement technology, without a Pigouvian tax abroad. In general, the imposition of a standard involves a trade-off as it will increase the cost of the foreign firms, which translates into lower output and higher import prices, but it also reduces the external effect per unit of output. Relative to a unilateral tariff, the imposition of a standard will also involve less distortion as the domestic country does not gain from the increase in the cost of foreign firms which results from the adoption of abatement technology.

In the context of our model, the government of the importing country will find it profitable to suppress the external effect altogether, i.e. to impose maximum abatement when the abatement technology is

9 The precise equivalence is however an artefact that results from the absence of consumption in the exporting country. 
Table 3.2 Output and welfare with abatement technology

\begin{tabular}{lllll}
\hline \hline & $\mathrm{X}$ & Welfare $\mathrm{H}$ & Welfare F & Total welfare \\
\hline FT & 0.500 & 0.000 & 0.125 & 0.125 \\
FB & 0.375 & & & 0.141 \\
UT & 0.250 & 0.094 & 0.031 & 0.125 \\
ST & 0.438 & 0.096 & 0.096 & 0.191 \\
$(k=0.5, z=0)$ & & & & \\
ST & 0.375 & 0.070 & 0.070 & 0.141 \\
$(k=1, z=0)$ & & & & \\
ST & & & & \\
$(k=2, z=0)$ & 0.250 & 0.031 & 0.031 & 0.063 \\
ST & 0.250 & 0.010 & 0.031 & 0.042 \\
$(k=3, z=0.083)$ & & & & \\
\hline \hline
\end{tabular}

ST: Shrimp-Turtle solution

$\mathrm{FT}=$ free trade, $\mathrm{FB}=$ first best, $\mathrm{UT}=$ unilateral import tariff

relatively efficient. In this instance, the US - Shrimp solution can actually improve welfare relative to free trade. It might also do better than the first best that can be achieved in the absence of abatement technology. It may also be attractive for the domestic government relative to the imposition of unilateral import tariff (despite the fact that the latter would bring revenues). The fact that the US - Shrimp solution is so attractive in this instance should not come as a surprise: it effectively provides an incentive to the government of the exporting country to use a very efficient technology that it has no incentive to use otherwise. Of course, the US - Shrimp solution always reduces welfare in the exporting country. This is illustrated in table 3.2, which for the sake of illustration assumes a linear abatement technology of the form $C(z)=k(\bar{z}-z)$, with $k=0.5$.

Table 3.2 also illustrates the outcome of a US-Shrimp policy in the case where the resource cost of reducing the externality (per unit of output) is equal to its utility cost, i.e when $k=1$. In this instance, the government of the importing country still imposes a policy of complete abatement and, unsurprisingly, the US -Shrimp solution then replicates the first best that can be achieved without abatement.

For less efficient abatement technology, the government of the importing country will still impose complete abatement. As long as the resource cost of abatement is reasonably close to the cost of the external effect 
( $k<1.1725$, in our benchmark case), the US - Shrimp solution will still do better than free trade. This arises because even though the US - Shrimp solution reduces output and trade, it also suppresses the external effect.

The importing country's government will actually find it profitable to impose a complete abatement even for very inefficient technologies, up to a resource cost of abatement which is twice as high as the utility cost (i.e. up to $k=2$ ) in the context of our benchmark. The importing country's government will thus impose very high standards and obtain little benefit from them overall but impose a strong burden on the exporting country. For even less efficient technologies, the importing country's government will choose incomplete abatement standards. Its optimal policy does not involve further reductions in output - so that the welfare of the foreign country does not fall any further. This is illustrated at the bottom of table 3.2, which presents the US - Shrimp solution for $k=2$ and $k=3$.

Let us now allow the exporting country's government to impose a Pigouvian tax. In this context, the firms will have the choice between adopting the abatement technology or paying the Pigouvian tax. We assume that they will choose the combination which minimizes cost. As shown by Ludeman and Wooton (1994), for any level of Pigouvian tax chosen by the exporting country, the importing country's government will have an incentive to set a standard which is binding, i.e. which requires an abatement level in excess of the abatement that would be induced by the tax. Since higher taxes induce higher abatement by exporting firms, the best reply of the importing country's government will involve an even higher standard (a lower $z$ ) than what would be implied by the tax.

The reaction of the importing country's government is thus downward sloping (in the $(e, z)$ space). Considering the incentive of the exporting country's government, for any level of abatement chosen by the importing country, it will have an incentive to set an externality tax which at most induces the abatement which is imposed by the importing country. If it chooses a tax which exactly induces the abatement imposed by the importing country, since higher abatement standards (a lower $z$ ) are induced by higher externality taxes, its reaction will be downward sloping. If it chooses to set a tax below the level which would induce the abatement standard imposed by the importing country, it will impose the optimal export tax. As shown by Ludema and Wooton (1994), this tax is also declining with the level of abatement chosen by the importing country, so that the reaction function of the foreign government is also downward sloping. The reaction function of both governments (in the $(e, z)$ space) are thus downward sloping. 
Hence, allowing the exporting country's government to introduce Pigouvian taxes will lead, if anything, to even higher abatement standards and lower output than the ST solution considered above. In the context of our benchmark model, the importing country's government found it profitable to impose full abatement for a wide range of abatement technology, in the absence of a Pigouvian tax abroad. For relatively ineffective abatement technologies, the outcome will be unaffected. There will be full abatement and, as a consequence, the externality tax will be not yield any revenue. ${ }^{10}$

\section{Conclusion}

From a legal perspective, the AB's most significant holding in the 21.5 ruling, that a multilateral agreement does not have to be concluded (even imminent) for Article XX.g GATT to be invoked, follows logically from the text and structure of XX.g, as well as the AB's original holding that nothing in Article XX GATT excludes from its ambit measures that are aimed at conditioning imports on the policies of another WTO Member (original AB ruling, para. 121). On its face, Article XX.g GATT creates rights that can be exercised by a WTO Member acting without the consent of other States. It is thus different from some other kinds of limitation or exception provisions in the GATT, which do imply that the actions in question must take place within some kind of collective framework; for example, Article XX1.c GATT creates an exception that can only be invoked where Members are taking action "in pursuance of ... obligations under the United Nations Charter for the maintenance of international peace and security."

Nor is the conception of a unilateral invocation of Article XX.g GATT rights at odds with general notions of sovereignty in international law. Environmentally based trade action, like that of the US in this case, has often been attacked as "extra-territorial." However, no control over foreign territory is being asserted; the US is merely deciding not to allow imports to enter its territory unless they meet certain conditions. It is not prescribing any environmental standards that would be binding on the territory of any other state (see Howse and Regan, 2000). The International Court of Justice has held that economic pressure on another state

${ }^{10}$ Our benchmark model is however ill-suited to consider this case. With linear abatement technology, the choice of whether to abate or pay the tax is discrete - so that there is either full abatement or no abatement at all. 
to change its policy, including in the form of an embargo, is not a per se violation of any rule of customary international law. ${ }^{11}$

It is true, in a general (non-legal) sense that the United States is in effect imposing on the exporting State some of the costs of the externality arising from sea turtles being endangered. But, some of these costs have been created in the first place by the economic activity of the exporting State. Why should the exporting State's "right" to create such externalities and impose them on the community of States be a more legitimate or superior attribute of sovereignty, than the sovereign "right" to take actions, otherwise legal under international law, to shift back some of those costs onto the exporting state? If one were to analyze the problem in this manner, and take into account the commitment to sustainable development in the Preamble of the WTO Agreement, the hierarchy would, if anything, be exactly the reverse.

From an economic perspective, it appears first that the US - Shrimp solution, which makes imports contingent on the adoption of an abatement standard can be a very effective way of addressing external effects across jurisdictions, at least when efficient abatement technology is available. In this instance, it provides exporters with appropriate incentive to adopt an efficient technology that they would not adopt otherwise and the US Shrimp solution will typically yield a more efficient allocation than free trade.

However, when abatement technology is poor, the US - Shrimp solution will be very inefficient. In this instance, the importing country will impose strict abatement standards that hardly improve on its own welfare but greatly reduce welfare abroad and the Shrimp/Turtle solution will do much worse than free trade. Second, it appears that when abatement technology is inefficient, making trade contingent on the adoption of externality taxes in the foreign country would yield a superior outcome.

Third, the implementation of the US - Shrimp solution always reduces welfare in the exporting country, relative to free trade. By contrast, making trade contingent on the adoption of Pigouvian taxes (at a rate determined by the importing country) can increase the welfare in both importing and exporting countries, relative to free trade.

Fourth, it appears that the effectiveness of the US - Shrimp solution is affected by the range of policies available in the exporting country, and in particular whether the exporting country can charge Pigouvian taxes as a response to the imposition of abatement standards.

11 Military and Paramilitary Activities (Nicaragua v. United States) 1986 I. C. J. 14, 125-26. 
These observations provide at least two insights with respect to the US - Shrimp ruling. First, in future cases, in considering the fit between a Member's measure and its environmental objective, the adjudicator should take into account the relative efficiency of the various policy instruments that a Member may choose to impose on another Member as a condition of access for its imports. In designing the conditions for imports, the adjudicator may also want to consider the range of policies available to the exporting country.

Second, it appears that the AB's acceptance that the US allowance for policies comparable in effectiveness to the Turtle Excluder Devices standard provided adequate flexibility could have inefficient consequences (although not necessarily). Indeed, if there are large differences in the cost of abatement across jurisdictions, it will be efficient to induce an allocation of abatement effort such that the marginal cost of abatement is uniform (assuming that the marginal benefit is constant). This will lead to the imposition of different environmental standards across jurisdictions. Hence, it would have been appropriate for the AB to clarify what is meant by "comparable in effectiveness" and indicate that comparable effectiveness does not imply that different jurisdictions should reach similar standards ${ }^{12}$ but rather that the marginal effectiveness of resources invested in abatement should be comparable across countries.

The framework that we have used has focused on the external effect and the ability to affect the terms of trade as sole sources of distortion. The analysis reveals that when other distortions do not matter, and, in particular, when conditions of supply are competitive, the US - Shrimp solution has desirable features. Arguably, however, this framework does not do justice to the concern being voiced about green protectionism.

In our framework, the domestic government has no incentive to raise the cost of foreign firms. Such an incentive may arise in the presence of imperfect competition to the extent that an increase in the cost of foreign firms will then shift profits to domestic firms. ${ }^{13}$ The domestic government may then be tempted to exploit situations where domestic abatement costs are low relative to abatement costs abroad. If the US Shrimp ruling is interpreted as allowing for the achievement of similar

12 The fact that the $\mathrm{AB}$ refers to policies that are comparable in effectiveness to TED suggests that the $\mathrm{AB}$ may have been thinking in terms of policies that yield comparable results at least if one assumes that Turtle Excluder Device technology is equally effective across jurisdictions.

13 As usual, a bias in favor of producer surplus induced by a particular political economy environment would yield the same result. 
standards, it will offer the scope for such "green protectionism." However, if the US - Shrimp ruling is interpreted as imposing the investment of abatement resources with comparable marginal effectiveness, the scope for protectionism will be greatly reduced. This further underlines the need to clarify what is meant by "comparable in effectiveness."

This discussion also implies that an effective implementation of the US - Shrimp solution requires some knowledge of abatement costs across jurisdictions. Whether the $\mathrm{AB}$ is well placed to evaluate these facts is an open question. It also raises the prospect that exporting countries may want to adopt policies, prior to the imposition of the US-Shrimp solution, to induce the importing country to infer that its cost of abatement is higher than the actual cost that would be incurred. Countries with low abatement costs could for instance generate large external effects so as to "pool" themselves with countries with high abatement costs. ${ }^{14}$

Our discussion of the US - Shrimp solution has also not considered many alternatives, and in particular it has not taken into account whether international negotiations on environmental policies could be expected to achieve a more efficient outcome. ${ }^{15}$ It is beyond the scope of this report to comment on this issue in depth. Let us only note that international agreements on environmental policies face considerable problems of compliance ${ }^{16}$ (see for instance, the survey by the OECD, from 1999).

The solution allowed in US - Shrimp, by contrast, may be less prone to compliance problems: if the exporting country has an incentive to shirk and not implement the policy, the importing country maintains clear incentive to monitor its implementation and a credible threat to prevent imports in case of non-compliance.

${ }^{14}$ Chang (1997) discusses such a mechanism in the context of international agreements. Given the problems of pooling that he identifies, he advocates the use of US - Shrimp type instruments (what he refers to as sticks - rather than the carrots that are assimilated with international agreements). Our discussion suggests however that a proper implementation of a US -Shrimp solution would also require addressing information asymmetries. In both instances, it would be necessary to separate high abatement countries from low abatement ones. The problems of asymmetric information that he identifies are pervasive.

15 As discussed by Howse (2002), the US - Shrimp solution could also be seen as a threat that could help ensure compliance in international agreements. One may not however want to presume that the US - Shrimp solution will be always inferior to the outcome of an international agreement.

16 The extent to which international agreements can effectively address external effects is sometimes questioned (irrespective of implementation issues). It may be useful to note in this respect that even in the US, which achieves a remarkable degree of coordination between constituent states, external effects across states are poorly internalized (see for instance, Revesz, 2000). 
Finally, our framework has not considered the complexities that would arise in the case of several importing nations, which could make their imports contingent on different abatement standards. ${ }^{17}$ To the extent that the implementation of standards is subject to scale economies, it would seem that the standards imposed by large importers would have a better chance of prevailing.

As noted above, the $\mathrm{AB}$ in the original case ruled that the blanket imposition of Turtle Excluder Devices would violate the chapeau. The $\mathrm{AB}$ has also ruled that conditioning access on the implementation of policies that are comparable in effectiveness would be compatible with the flexibility requirements of the chapeau.

The ruling of the $\mathrm{AB}$ was clearly motivated by the desire to accommodate local circumstances. However, a situation might arise where a Member requires only that the exporting country adopt a scheme comparable in effectiveness in achieving a given level of environmental protection, without specifying a particular instrument or technology that will be deemed to satisfy this standard. Of course, this was not the case in the US - Shrimp dispute, because it was always possible under section 609 for an exporting country to comply by adopting Turtle Excluder Devices, if it so chose.

But where there is no clear benchmark, flexibility may in turn raise additional concerns about protectionist abuse, which would need to be addressed under the chapeau. Assume, for instance, that one importing country is motivated by the desire to protect its domestic industry and uses environmental protection merely as an instrument for raising import barriers. This country will have an incentive to accept only those programs that are excessively costly to the exporting country and its industry.

Such behavior could of course trigger further complaints in WTO dispute settlement about the application of the scheme in question. However, in the current framework of dispute settlement, the importing country would be allowed to implement its strict certification until a final ruling by the $\mathrm{AB}$ and it would never be asked to pay compensation for the period preceding the ruling if its certification is considered to be unlawful. The importing country could then seemingly comply but make only cosmetic changes to its certification and obtain the benefit of protection until the final compliance ruling. In principle, nothing would actually prevent the

17 As indicated above, these complexities were emphasized by the panel ruling in the original case. 
importing country from endless rounds of cosmetic changes and from never actually complying (see Anderson, 2002). ${ }^{18}$

Of course, the scope for such opportunistic behavior will be greater if the equivalence between abatement programs is formulated in general principles rather than precise rules. General principles will allow for a more precise tailoring of abatement programs to local conditions. But precise rules, whose implementation is easy to verify, will be more difficult to abuse.

Overall, it appears that it may be appropriate for the $\mathrm{AB}$ to insist that flexibility be accompanied by transparent guidelines or rules that limit the discretion of authorities in making case-by-case decisions as to which programs are effective in meeting the environmental objectives. In fact, this is consistent with the emphasis on due process and transparency in the portion of the original AB ruling that addresses "arbitrary discrimination" under the chapeau. In this respect, in order the ensure that the application of a scheme is consistent with the chapeau, the scheme itself, or at least rule-making pursuant to it, may have to contain certain kinds of features.

This raises an important point about the relationship of the chapeau to the measure itself. While, as the $\mathrm{AB}$ correctly has held in US - Shrimp, the chapeau conditions concern application of a measure, there may be certain cases where the design of the measure itself may be highly relevant to whether its application will violate the chapeau or not. The adjudicator may then need in certain instances to concern itself with aspects of the measure itself in applying the chapeau, something that was of course not the case on the US - Shrimp facts. But this is consistent with the view of state responsibility in the S. 301 panel - there may be features of a scheme that do not as such compel a violation of WTO rules, but which create a serious threat that the rules will be violated when the scheme is applied.

\section{References}

Anderson, K. (2002), Peculiarities of retaliation in WTO dispute settlement, World Trade Review, 1(2), July.

Bhagwati, J. (2001).

Chang, H. (1997), Carrots, sticks and international externalities, International Review of Law and Economics, 17, 309-324.

${ }^{18}$ If such opportunistic behavior is allowed to prevail, the incentive to use the dispute settlement mechanism and the incentive to reach a multilateral agreement in the first place may be seriously impaired. 
Howse, R. (2002), The Appellate body rulings in the Shrimp/turtle case: a new legal baseline for the trade and environment debate, Columbia Journal of Environmental Law, 27(2), 491-521.

Howse, R. and D Regan (2000). The Product/Process Distinction - An Illusory Basis for Disciplining "Unilateralism" in Trade Policy, European Journal of International Law, 11(1), 249-283.

Ludema, R. and I. Wooton (1994), Cross-border externalities and trade liberalization: the strategic control of pollution, The Canadian Journal of Economics, 27(4), 950-966.

OECD (1999), Trade measures in multilateral environmental agreements, OECD, Paris.

Revesz, R. (2000), Federalism and regulation: extrapolating from the analysis of environmental regulation in the United States, Journal of International Economic Law, 219-233.

\section{Appendix}

1. The free trade solution, the intersection between export supply and import demand is given by:

$$
x=\frac{a-f}{b+g}
$$

2. The first-best solution maximizes the sum of importing and exporting countries' welfare, with respect to an externality tax and the constraint that demand is equal to supply, i.e.

$$
\begin{gathered}
\max _{t} \frac{b x^{2}}{2}+(t-\bar{z}) x+\frac{g x^{2}}{2}, \\
\text { s.t. } x=\frac{a-f-t}{b+g}
\end{gathered}
$$

The first-order condition for this problem implies:

$$
\begin{aligned}
t^{*} & =\bar{z} \text { and } \\
x & =\frac{(a-f-\bar{z})}{(b+g)}
\end{aligned}
$$

3. The optimal unilateral import tariff solves:

$$
\begin{array}{r}
\max _{r} \frac{b x^{2}}{2}+(r-\bar{z}) x, \\
\text { s.t. } x=\frac{a-f-r}{b+g}
\end{array}
$$


Solving the f.o.c yields:

$$
\begin{aligned}
r^{*} & =\bar{z}\left(\frac{b+g}{b+2 g}\right)+\frac{(a-f) g}{b+2 g} \\
x & =\frac{(a-f-\bar{z})}{b+2 g}
\end{aligned}
$$

4. The externality tax on which trade can be made contingent solves:

$$
\begin{array}{r}
\max _{e} \frac{b x^{2}}{2}-(\bar{z}) x, \\
\text { s.t. } x=\frac{a-f-e \bar{z}}{b+g}
\end{array}
$$

The problem is convex and the objective function is equal to zero for $e=\frac{(a-f)}{\bar{z}}$. Hence if $(b x-\bar{z})>0$, for $e=0$, the maximum is reached for $e=0$. If $(b x-\bar{z})<0$, for $e=0$, the maximum is reached for $e=\frac{(a-f)}{\bar{z}}$. In this case, the externality tax is prohibitive. It is set at a level which prevents trade.

5. The Nash equilibrium of the game in which the importing country sets an import tariff and the exporting country sets an externality tax simultaneously solves:

$$
\begin{gathered}
\max _{r} \frac{b x^{2}}{2}+(r-\bar{z}) x \text { and } \max _{e} \frac{g x^{2}}{2}+e \bar{z} x, \\
\text { s.t. } x=\frac{a-f-(r+e \bar{z})}{b+g}
\end{gathered}
$$

The solution to this problem is given in equation (8) of Ludema and Wooton (1994) and replacing $e \bar{z}=s$.

6. The US - Shrimp solution solves the following problem:

$$
\begin{aligned}
\max _{z} \frac{b x^{2}}{2} & +z x, \\
\text { s.t. } x & =\frac{a-f-C(z)}{b+g}
\end{aligned}
$$

Assuming that $C(x)=k(\bar{z}-z)$, the f.o.c for the problem yields:

$$
z^{*}=\max \left[0, \frac{(a-f-k \bar{z})(k b-(b+g))}{\left(2 k(b+g)-k^{2} b\right)}\right]
$$

For $(k b-(b+g))>0$ and $\left(2 k(b+g)-k^{2} b\right)>0$, we have $z^{*}>0$. 